\title{
ANALISIS PENGARUH FAKTOR-FAKTOR FUNDAMENTAL KINERJA BANK DAN MAKRO EKONOMI TERHADAP STABILITAS PERBANKAN DI INDONESIA
}

\begin{abstract}
Ririt Iriani Sri Setiawati ${ }^{*}$
${ }^{U}$ PN Veteran Jawa Timur, Indonesia

INFO ARTIKEL

DOI:10.32812/jibeka.v14i2.194

ISSN-P: 0126-1258

ISSN-E: 2620-875X

Keywords: Banking Stability, $L D R, N P L, C A R$, BI Rate, and Inflation

ABSTRACT

Bank financial institutions are part of the financial system has a significant impact on the economy in Indonesia. Therefore, banks should be able to keep and maintain stability in the financial sector properly. The experience of the financial crisis in the 1998/1999 era, one at a bank went bankrupt and be the cause of severe economic crisis makes Indonesia improve its financial system. This study aimed to analyze the influence of fundamental factors and macro-economic performance of the bank to the stability of banks in Indonesia during the period 2011-2017. Fundamental factors indicated by the LDR, NPL and CAR. Meanwhile, macroeconomic factors indicated by variable $B i$ rate and inflation. Banking stability is reflected by the banking stability index. This study uses a quantitative approach to the panel regression analysis model data and a sample of 29 commercial banks in Indonesia by using the tools of the computer program eviews 10. The results of these empirically demonstrated that simultaneous, variable factors of fundamental and macroeconomic factors have a significant influence on the stability of perbankan. While partially, the results of this study indicate that the variable $L D R, N P L, B i$ rate and inflation significant influence on the stability of the banking and CAR variables not significant effect on the stability of the banking system.
\end{abstract}

\section{ABSTRAK}

Lembaga keuangan bank merupakan bagian dari sistem keuangan mempunyai pengaruh yang cukup signifikan terhadap perekonomian di Indonesia. Oleh karena itu, bank harus mampu menjaga dan memelihara kestabilan sektor keuangan dengan baik. Pengalaman krisis keuangan di era tahun 1998/1999, satu per satu bank mengalami kebangkrutan dan menjadi penyebab krisis ekonomi yang parah membuat Indonesia memperbaiki sistem keuangannya. Penelitian ini bertujuan untuk menganalisis pengaruh faktor-faktor fundamental kinerja bank dan makro ekonomi terhadap stabilitas perbankan di Indonesia selama periode tahun 2011-2017. Faktor fundamental ditunjukkan dengan rasio LDR, NPL, dan CAR. Sedangkan, faktor makro ekonomi ditunjukkan dengan variabel $\mathrm{Bi}$ rate dan inflasi. Stabilitas perbankan dicerminkan dengan indeks stabilitas perbankan. Penelitian ini menggunakan pendekatan kuantitatif dengan model analisis regresi panel data dan sampel sebanyak 29 bank umum di Indonesia dengan menggunakan alat bantu program komputer eviews 10. Hasil penelitian ini menunjukkan bahwa secara simultan, variabel faktorfaktor fundamental dan faktor makro ekonomi mempunyai pengaruh signifikan terhadap stabilitas perbankan.Sedangkan, secara parsial, hasil penelitian ini menunjukkan bahwa variabel LDR, NPL, Bi rate dan inflasi mempunyai pengaruh signifikan terhadap stabilitas perbankan dan variabel CAR berpengaruh tidak signifikan terhadap stabilitas perbankan. 


\section{Pendahuluan}

Keberadaan sektor keuangan dalam sebuah perekonomian memiliki peran yang sangat penting dalam rangka meningkatkan pertumbuhan ekonomi (Jamili, 2017; Purboyanti \& Yogatama, 2018). Sektor keuangan dapat menjadi pergerakan pertumbuhan sektor riil melalui penambahan modal dan inovasi teknologi (Cahyaningrum, 2017; Gunawan, 2019; P. Simatupang et al., 2016). Lebih tepatnya, sektor keuangan mampu menghimpun dana masyarakat dan menyalurkannya dalam bentuk kredit yang tak lain yaitu produk tabungan. Berbagai instrumen keuangan dikemas dengan baik dengan kualitas tinggi dan risiko rendah agar menarik minat masyarakat sebagai peminjam dan penyimpan dana. Perekonomian yang kuat, stabil, dan berdaya saing sangat membutuhkan pendanaan dari sektor keuangan non perbankan maupun perbankan yang bekerja secara efisien (Cahyaningrum, 2017; Gunawan, 2019; Jamili, 2017; Purboyanti \& Yogatama, 2018; Ramly \& Hakim, 2017). Hal ini dikarenakan, perekonomian membutuhkan likuiditas dalam menjalankan segala transaksi ekonomi (Gunawan, 2019; Setiawan \& Pratama, 2019; Siahaan \& Asandimitra, 2018).

Pertumbuhan sektor ekonomi akan bergerak secara optimal apabila mampu menjaga dan memelihara kestabilan sektor keuangan tersebut dengan baik. Di Indonesia, sektor keuangan masih didominasi oleh sektor perbankan (Gunawan, 2019; Risal, 2019; Setiawan \& Pratama, 2019; Utami, 2018). Hal ini akan menimbulkan tingginya ketergantungan kepada perbankan sebagai sumber perekonomian negara. Dengan demikian, apabila sektor perbankan tidak dapat menyalurkan pendanaan dengan baik kepada sektor riil, maka berpengaruh terhadap kelambatan pertumbuhan ekonomi (Gunawan, 2019; Risal, 2019; Setiawan \& Pratama, 2019; Utami, 2018).

Sektor perbankan mempunyai peran yang sangat penting dalam menjaga stabilitas perekonomian suatu negara (Fahrial, 2018; Setiawan \& Pratama, 2019; Utami, 2018). Perbankan menjalankan peran sebagai perantara keuangan kepada dua pihak, yaitu pihak yang kelebihan dana dan pihak yang kekurangan dana. Oleh karena itu, peran perbankan di atas dapat disebut sebagai Lembaga intermediasi keuangan (financial Intermediary Institution) yang berdasarkan pada Undang - Undang Nomor 10 Tahun 1998 Pasal 1 Angka 2 tentang Perubahan atas Undang - Undang Nomor 7 Tahun 1992 yakni bahwa Bank adalah badan usaha yang menghimpun dana dari masyarakat dalam bentuk simpanan dan menyalurkannya kepada masyarakat dalam bentuk kredit dan atau bentuk-bentuk lainnya dalam rangka meningkatkan taraf hidup rakyat banyak (Fahrial, 2018; Setiawan \& Pratama, 2019; B. Simatupang, 2019; Utami, 2018).

Besarnya aset perbankan dalam kurun waktu terakhir ini, menunjukkan perkembangan yang sangat signifikan, akan tetapi dalam usaha pencapaian tersebut, tentunya banyak mengalami pasang surut. Jauh berbeda sekali saat ini dengan dua puluh tahun yang lalu ketika krisis moneter. Menurunnya nilai tukar rupiah pada pertengahan tahun 1997, mengakhiri maraknya industri perbankan di era 1990-an. Satu per satu bank mengalami kebangkrutan dan menjadi penyebab krisis ekonomi yang sangat parah di Indonesia saat itu. Pasca penerbitan paket deregulasi perbankan pada tanggal 27 Oktober 1998 (PAKTO) yang memiliki isi pokok yaitu memberikan kemudahan perizinan pendirian bank baru, termasuk pembukaan kantor cabang (Fahrial, 2018; Setiawan \& Pratama, 2019; Widyastuti \& Armanto, 2013). Setelah dikeluarkannya kebijakan tersebut, jumlah bank di Indonesia terus mengalami peningkatan karena kemudahan perizinan yang diberikan oleh Bank Indonesia. Namun, setelah krisis ekonomi yang melanda Indonesia, banyak bank yang harus dilikuidasi. Tercatat pada tahun 1998 jumlah bank yang beroperasi adalah 208 bank namun pada tahun 1999 turun menjadi 164 bank dan sampai tahun 2017 jumlah bank yang masih beroperasi sejumlah 116 bank (Setiawan \& Pratama, 2019; B. Simatupang, 2019; Utami, 2018; Widyastuti \& Armanto, 2013).

Stabilnya sistem perbankan ditunjukkan dengan kondisi perbankan yang sehat dan berjalannya fungsi intermediasi dengan baik. Apabila kondisi tersebut terpelihara dengan baik, maka proses perputaran uang dan mekanisme transmisi kebijakan moneter dalam perekonomian yang sebagian besar berlangsung melalui sistem perbankan juga akan berjalan baik (Acharya \& Ryan, 2016; Ntarmah et al., 2019; Setiawan \& Pratama, 2019; 
Siahaan \& Asandimitra, 2018). Dengan demikian, terjaganya stabilitas moneter akan berpengaruh besar bagi stabilitas perbankan. Perkembangan inflasi, suku bunga, dan nilai tukar menjadi tiga elemen utama dalam menghadapi risiko pasar perbankan. Dengan demikian, apabila ketiga indikator ini berlangsung stabil, maka resiko yang dihadapi perbankkan akan semakin kecil sehingga membantu terjaganya stabilitas perbankkan. Sebaliknya, apabila terjadi pelemahan nilai tukar meningkat dan tekanan inflasi, maka risiko pasar yang dihadapi perbankkan akan semakin besar sehingga pihak bank akan melakukan pengetatan dengan menaikkan suku bunga yang tinggi. Tentunya, hal ini akan membawa pengaruh yang negatif terhadap stabilitas sistem perbankan (Adrian \& Liang, 2016; AlKhouri \& Arouri, 2016; Bohl et al., 2016; Jayakumar et al., 2018; Ntarmah et al., 2019; Widyastuti \& Armanto, 2013).

Pemeliharaan stabilitas mutlak dilakukan oleh perbankkan itu sendiri dengan gambaran kinerja bank secara keseluruhan. Kinerja bank akan menggambarkan apakah sektor perbankkan dalam keadaan stabil atau tidak. Kinerja bank dapat dilihat dari beberapa aspek, diantaranya likuiditas, kualitas aset, kecukupan modal dan profitabilitas. Bank yang semakin baik kinerjanya akan membantu menjaga stabilitas perbankkan yang nantinya akan mendukung terjaganya stabilitas keuangan juga (Acharya \& Ryan, 2016; Adrian \& Liang, 2016; Bohl et al., 2016; Ozili, 2019). Likuiditas merupakan kemampuan bank dalam memenuhi kewajibannya terutama kewajiban jangka pendek. Selain itu, kualitas aset merupakan kemungkinan diterimanya kembali dana yang ditanamkan dalam aktiva produktif maupun non produktif kepada pihak ketiga dengan kriteria tertentu untuk memberi manfaat bagi bank tersebut. NPL (Non Performing Loan) dijadikan alat ukur rasio kualitas aset, karena semakin tinggi nilai NPL mencerminkan semakin buruk kualitas kredit bank yang menyebabkan jumlah kredit bermasalah semakin besar dan bank mengalami kerugian. Selain itu, kinerja bank dapat dinilai dari kecukupan modal yang menjadi hal penting dalam berdirinya suatu bank, karena menunjukkan kemampuan bank dalam menyediakan dana yang digunakan sebagai cadangan untuk mengatasi kerugian sebagai akibat dari aktiva yang berisiko seperti penyaluran kredit, penyertaan surat berharga, maupun tagihan pada bank lain yang harus dibiayai oleh modal sendiri (Chiesa \& Mansilla-Fernandez, 2018; Ozili, 2019; Yang, 2017).

Faktor utama yang menyebabkan naik turunnya stabilitas perbankan dipengaruhi oleh faktor internal dan eksternal. Faktor internal disebut juga faktor fundamental adalah faktor yang berasal dari dalam perusahaan dan dapat dikendalikan oleh manajemen perusahaan, sedangkan faktor eksternal yang merupakan faktor non fundamental biasanya dapat disebabkan oleh kondisi ekonomi seperti suku bunga dan kebijakan pemerintah (Natarsyah, 2000). Faktor fundamental yang dibahas dalam penelitian ini adalah, LDR (Loan to Deposit Ratio), NPL (Non Performing Loan) dan CAR (Capital Adequacy Ratio). Sedangkan, faktor makro ekonomi yang mempengaruhi di luar kinerja bank yang akan dibahas dalam penelitian ini adalah inflasi dan BI Rate. Perbedaan penelitian ini dengan penelitian sebelumnya terletak pada penggunaan variabel Indeks Stabilitas Perbankan yang diukur dengan variabel Z-score bank untuk menilai tingkat stabilitas perbankkan sedangkan dalam penelitian ini menggunakan data Indeks Stabilitas Perbankan. Penelitian ini bertujuan untuk menganalisis pengaruh faktor fundamental kinerja bank yang diproksikan dengan LDR (Loan to Deposit Ratio), NPL (Non Performing Loan), CAR (Capital Adequacy Ratio) dan faktor makro ekonomi yang diproksikan dengan $\mathrm{BI}$ rate dan inflasi terhadap stabilitas perbankan di Indonesia.

\section{Metode Penelitian}

Penelitian ini menggunakan metode random sampling atau probability sampling, sedangkan cara pengambilan sampel yang digunakan adalah simple random sampling. Probability sampling adalah teknik pengambilan sampel yang memberi peluang atau kesempatan sama bagi setiap unsur atau anggota populasi untuk dipilih menjadi sampel, sedangkan simple random sampling digunakan sebagai pengambilan sampel dalam penelitian ini karena pengambilan anggota sampel dari populasi dilakukan secara acak 
tanpa memperhatikan strata yang ada dalam populasi itu. Populasi yang digunakan dalam penelitian ini adalah bank umum konvensional yang terdaftar di Bank Indonesia dan Otoritas Jasa Keuangan (OJK). Dengan jumlah seluruh populasi sebanyak 115 bank di Indonesia pada tahun 2017. Maka merujuk pada pendapat diatas jumlah sampel dalam penelitian ini dapat diambil $25 \%$ dari jumlah populasi. Maka didapat jumlah sampel untuk penelitian ini sebesar 29 bank umum di Indonesia. Data yang digunakan dalam penelitian adalah data sekunder. Data diperoleh dari website resmi dari instansi terkait seperti Bank Indonesia, Badan Pusat Statistik (BPS), Lembaga Penjamin Simpanan (LPS), dan masing-masing bank yang digunakan sampel dalam penelitian untuk memperoleh laporan keuangan bank. Penelitian ini menggunakan analisis regresi data panel (Pooled data) yang merupakan gabungan antara data time series dan data cross section yakni beberapa objek penelitian dengan beberapa periode waktu atau tahun. Teknik ini digunakan untuk menganalisis pengaruh faktor fundamental kinerja bank yang yang ditunjukkan dengan LDR, NPL, CAR dan faktor makro ekonomi yaitu BI Rate dan Inflasi terhadap stabilitas perbankan di Indonesia. Adapun model yang digunakan dalam metode ini adalah sebagai berikut:

$$
\text { Stabilitas }_{i t}=\alpha+\beta_{1} \mathrm{LDR}_{\mathrm{it}}+\beta_{2} \mathrm{NPL}_{\mathrm{it}}+\beta_{3} \mathrm{CAR}_{\mathrm{it}}+\beta_{4} \mathrm{Bi}_{\mathrm{i}} \text { rate }_{\mathrm{it}}+\beta_{5} \text { Inflasi }_{\mathrm{it}}+e_{\mathrm{it}}
$$

\section{Hasil Penelitian dan Pembahasan}

Pada estimasi analisis pengaruh faktor-faktor fundamental dan makro ekonomi terhadap stabilitas perbankan di Indonesia tahun 2011-2017 menggunakan regresi data panel. Hasil analisis untuk mengetahui model terbaik dalam penelitian ini dilakukan dengan pengujian yaitu uji chow dan uji Lagrange Multiplier (LM) sehingga dapat diketahui model regresi yang tepat yaitu model Common Effect, Fixed Effect atau Random Effect.

Berdasarkan hasil output uji chow, nilai F-test maupun nilai chi-square yaitu sebesar 1,0000 lebih besar dari 0,05. Ini berarti bahwa hipotesis null diterima, sehingga metode CEM lebih baik dibandingkan dengan metode FEM. Setelah didapat hasil bahwa metode Common Effect lebih baik dibandingkan Fixed Effect, maka langkah selanjutnya yaitu menguji untuk membandingkan antara metode CEM dengan REM. Uji yang dilakukan untuk menguji hal tersebut adalah dengan Lagrange Multiplier Test. Dari hasil pengujian dengan uji Lagrange Multiplier (LM) ternyata nilai LM hitung atau Breusch Pagan adalah 0,0001 $(<0,05)$, maka model yang terpilih adalah Random Effect.

Tabel 1. Hasil Analisis

\begin{tabular}{cccccc}
\hline $\begin{array}{c}\text { Variabel } \\
\text { terikat }\end{array}$ & $\begin{array}{c}\text { Variabel } \\
\text { bebas }\end{array}$ & $\begin{array}{c}\text { Koefisien } \\
\text { Regresi }\end{array}$ & t statistic & Probabilitas & Keterangan \\
\hline \multirow{3}{*}{ Indeks } & LDR & 9.945033 & 5.684486 & 0.0000 & Sig. \\
Stabilitas & NPL & 0.082585 & 17.60542 & 0.0000 & Sig. \\
Perbankan & CAR & $7.52 \mathrm{E}-05$ & 0.797466 & 0.4261 & Tidak Sig. \\
& BI RATE & 0.363266 & 35.02992 & 0.0000 & Sig. \\
& INFLASI & 0.015371 & 2.469816 & 0.0144 & Sig. \\
\hline
\end{tabular}

Sumber: Penulis, 2020

Tabel 2. Hasil Uji F

\begin{tabular}{cccccc}
\hline Uji & R-squared & $\begin{array}{c}\text { Adjusted R- } \\
\text { squared }\end{array}$ & $\begin{array}{c}\text { S.E. of } \\
\text { regression }\end{array}$ & F-statistic & Prob(F-statistic) \\
\hline Hasil & 0.937476 & 0.935889 & 0.130777 & 5.907 .587 & 0.000000 \\
\hline
\end{tabular}

Sumber: Penulis, 2020

Uji $\mathrm{F}$ digunakan untuk menguji hubungan secara simultan yang bertujuan untuk mengetahui apakah seluruh variabel independen bersama-sama mempunyai pengaruh yang signifikan terhadap variabel dependen. Pengujian dilakukan dengan membandingkan antara F-hitung dan F-tabel pada taraf signifikansi sebesar 5\%. F-Statistik sebesar 590,76 dengan 
nilai probabilitas ( $\mathrm{F}$ signifikan) sebesar 0,0000 yang lebih kecil dari 0,05 menjelaskan bahwa model regresi tersebut dapat digunakan untuk memprediksi stabilitas perbankan yang berarti model tersebut layak atau secara simultan LDR, NPL, CAR, BI Rate, dan inflasi berpengaruh terhadap stabilitas perbankan. Uji $\mathrm{t}$ dilakukan untuk melihat signifikansi variabel bebas secara individu mempengaruhi variabel terikat dengan membandingkan antara t-hitung dan t-tabel pada taraf signifikansi sebesar $5 \%$.

Dalam penelitian ini diperoleh hasil dari kelima variabel bebas, LDR berpengaruh signifikan terhadap stabilitas perbankan, hal ini ditandai dengan nilai t-hitung sebesar $5,6845 \geq$ t-tabel 1,972 . NPL juga berpengaruh signifikan terhadap stabilitas perbankan dengan hasil t-hitung sebesar 17,60542 $\geq$ t-tabel 1,972, sedangkan variabel kinerja bank yang ditunjukkan dengan CAR tidak berpengaruh signifikan terhadap stabilitas perbankan, hal ini ditunjukkan dengan nilai t-hitung sebesar $0,7975 \leq \mathrm{t}$-tabel 1,972. Pada faktor makro ekonomi, kebijakan moneter BI Rate berpengaruh signifikan terhadap stabilitas perbankan, yang ditandai dengan nilai t-hitung sebesar $35.0299 \geq$ t-tabel 1,972. Untuk inflasi juga berpengaruh signifikan terhadap stabilitas perbankan, diperoleh nilai t-hitung sebesar 2.4698 $\geq$ t-tabel 1,972 .

Koefisien determinasi biasa digunakan untuk mengukur seberapa besar variasi variabel bebas dapat menjelaskan variabel terikatnya. Menurut Ghozali (2016), kelemahan mendasar penggunaan koefisien determinasi adalah bias terhadap jumlah variabel independen yang dimasukkan ke dalam model. Setiap tambahan satu variabel independen, maka $\mathrm{R}^{2}$ pasti meningkat tak peduli apakah variabel tersebut berpengaruh secara signifikan terhadap variabel dependen. Oleh karena itu, banyak peneliti menganjurkan untuk menggunakan nilai Adjusted $R^{2}$ pada saat mengevaluasi mana model regresi terbaik. Hasil analisis data panel pada tabel diatas menunjukkan nilai koefisien determinasi Adjusted $R$ Squared diperoleh sebesar 0,936 atau 93,6\%. Hal ini menunjukkan bahwa stabilitas perbankan di Indonesia dapat dijelaskan dengan variabel LDR, NPL, CAR, BI Rate, dan inflasi, sedangkan sisanya sebesar $6,4 \%$ dijelaskan oleh variabel lain yang tidak diikutsertakan dalam penelitian ini.

Dalam penelitian ini, karena yang terpilih model Random Effect, jadi hanya menggunakan multikolinearitas. Keuntungan menggunakan model Random Effect yakni menghilangkan heteroskedastisitas, sedangkan tidak dilakukan uji autokorelasi dikarenakan uji ini hanya terjadi pada data time series (Basuki \& Prawoto, 2016). Pengujian autokorelasi pada data yang tidak bersifat time series (cross section atau panel) akan sia-sia semata atau tidaklah berarti. Dalam penelitian ini, untuk menguji hipotesis tersebut dilakukan dengan cara melihat nilai Variance Inflation Factors (VIF). Apabila nilainya melebihi 10 , maka $\mathrm{H}_{0}$ yang menyatakan tidak terjadinya multikolinearitas dalam model ditolak. Artinya, model regresi mengandung masalah multikolinearitas. Berdasarkan nilai VIF, tidak ada variabel bebas yang memiliki nilai VIF pada Centered VIF yang melebihi 10. Dimana nilai Centered VIF dari LDR sebesar $1,016239<10$, NPL sebesar 1,044163 < 10, CAR sebesar 1,004653 < 10, BI Rate sebesar 1,880627 < 10, dan inflasi sebesar 1,887301<10. Berdasarkan hasil tersebut dapat disimpulkan bahwa masalah multikolinearitas tidak terjadi dalam model. Dari hasil uji simultan dapat diketahui bahwa secara keseluruhan variabel LDR, NPL, CAR, BI Rate, dan inflasi berpengaruh secara nyata terhadap stabilitas perbankan di Indonesia.

Untuk pengaruh LDR (Loan to Deposit Ratio) terhadap Stabilitas Perbankan, dari hasil estimasi panel data menunjukkan bahwa variabel LDR memiliki pengaruh positif terhadap indeks stabilitas perbankan. LDR sendiri merupakan rasio yang menunjukkan tingkat likuiditas perbankan. Apabila semakin tinggi rasio ini, maka semakin buruk juga tingkat likuiditas bank yang bersangkutan karena bank harus mencairkan aset yang dimiliki untuk membiayai kredit. Ketika rasio likuiditas perbankan mengalami kenaikan maka bank tersebut akan mengalami penurunan likuiditas. Penurunan likuiditas tersebut menimbulkan resiko jika tidak segera diatasi. Oleh karena itu jika rasio likuiditas ini mengalami peningkatan, maka stabilitas perbankan juga akan terganggu karena indeks stabilitas perbankan menunjukkan peningkatan. Hal ini sesuai dengan penelitian Saadet dan Adnan (2015) yang menunjukkan bahwa risiko likuiditas memiliki hubungan negatif terhadap z-score bank yang 
menunjukkan kestabilan bank. Selanjutnya adalah pengaruh NPL (Non Performing Loan) terhadap stabilitas perbankan. Mengacu pada hasill estimasi panel secara parsial menunjukkan bahwa NPL memiliki nilai signifikan terhadap indeks stabilitas perbankan. Dalam penelitian ini menunjukkan hubungan positif, berarti apabila nilai NPL mengalami kenaikan akan menyebabkan indeks stabilitas perbankan juga mengalami kenaikan yang artinya angka stabilitas perbankan akan mendekati masalah krisis.

Timbulnya kredit bermasalah dapat memberikan dampak hilangnya kesempatan untuk memperoleh income (pendapatan) dari kredit yang diberikannya, sehingga mengurangi perolehan laba dan berpengaruh buruk bagi stabilitas bank. Selain itu, pada tingkat pertumbuhan kredit macet yang tinggi membuat ketidaklancaran perputaran kas suatu bank. Apabila hal tersebut terus berlanjut maka terjadi penurunan kredit yang disalurkan oleh pihak bank kepada nasabah lain. Keadaan seperti ini membuat bank tidak lagi dapat memenuhi likuiditasnya atau dalam keadaan tidak likuid. Oleh karena itu, rasio NPL dan LDR ini mempunyai pengaruh yang kuat atas indeks stabilitas perbankan karena kedua rasio tersebut yang dijadikan indikator dalam perhitungan indeks stabilitas bank yang diterbitkan oleh Lembaga Penjamin Simpanan (LPS). Hasil penelitian ini sesuai dengan penelitian Al-khouri dan Arouri tahun 2016 yang menyatakan pada tingkat pertumbuhan kredit yang tinggi, bank menjadi kurang stabil (Al-Khouri \& Arouri, 2016). Terkait dengan pengaruh CAR (Capital Adequacy Ratio) terhadap stabilitas perbankan. Hasil estimasi panel secara parsial menunjukkan bahwa CAR memiliki nilai tidak signifikan terhadap indeks stabilitas perbankan. Hasil penelitian ini mengidentifikasi bahwa kecukupan modal yang diproksikan dengan CAR belum mampu meningkatkan kinerja bank umum dalam usahanya memperkuat stabilitas perbankan.

Pengaruh positif tidak signifikan CAR terhadap stabilitas perbankan ini diduga karena bank-bank sampel yang digunakan dalam penelitian ini merupakan bank dengan kategori bank besar, bank menengah, dan bank kecil sehingga bank yang mempunyai modal kecil akan cenderung semakin tinggi mengalami risiko kebangkrutan. Selain itu, bank yang mempunyai modal rendah akan sulit mendapatkan kepercayaan dari masyarakat sebagai penyimpan dana maupun pemegang saham. Hubungan kepercayaan inilah yang membuat bank-bank rentan mengalami krisis keuangan. Mengingat penelitian sebelumnya yang dilakukan oleh Fakhri Korbi dan Khemais Bougatef tahun 2017, yang menunjukkan rasio kecukupan modal justru berpengaruh positif terhadap kemungkinan kebangkrutan suatu bank (Korbi \& Bougatef, 2017). Mereka menyatakan fakta bahwa bank-bank yang bermodal besar lebih mampu mendapatkan kepercayaan pelanggan mereka dan sebagai akibatnya mereka lebih kecil kemungkinannya untuk mengalami kebangkrutan.

Selanjutnya adalah pengaruh BI Rate terhadap stabilitas perbankan. Hasil estimasi menunjukkan bahwa BI Rate memiliki nilai signifikan terhadap indeks stabilitas perbankan. $\mathrm{Hal}$ ini menunjukkan bahwa ketika tingkat suku bunga BI Rate mengalami peningkatan akan menyebabkan bank menjadi tidak stabil karena indeks stabilitas perbankan juga mengalami peningkatan. Hal ini sesuai dengan penelitian yang dilakukan oleh Rizky Yudaruddin tahun 2016 yang mengungkapkan bahwa suku bunga menunjukkan hasil positif signifikan terhadap stabilitas bank (Yudaruddin, 2016, 2018). Selain itu, Perry tahun 2006 yang menyatakan bahwa stabilitas sistem perbankan dan stabilitas moneter adalah dua aspek yang saling terkait dan menentukan satu sama lain (Warjiyo, 2006). Ketika stabilitas moneter terganggu maka otoritas moneter, dalam hal ini Bank Indonesia akan merespon melalui beberapa kebijakan seperti menaikkan atau menurunkan $\mathrm{Bi}$ rate agar stabilitas moneter dapat terjaga (Adrian \& Liang, 2016; Lamers et al., 2016; Warjiyo, 2006; Yudaruddin, 2016).

Perubahan suku bunga yang merupakan salah satu dari kebijakan moneter atau berpengaruh terhadap kesehatan dan kestabilan bank. Hal ini terkait dengan risiko pasar dan resiko kredit yang dihadapi oleh perbankan. Misalnya, jika inflasi dan nilai tukar berfluktuatif maka akan terjadi redistribusi aset riil dari masyarakat penyimpan dana (investor) kepada debitur kredit perbankan. Ketika Bank Indonesia memilih menaikkan suku bunga maka suku bunga kredit dalam perbankan akan ikut menyesuaikan kenaikannya. Ketika suku bunga kredit mengalami kenaikan maka risiko kredit debitur dapat meningkat 
sehingga permintaan riil akan kredit menurun, sehingga risiko perbankan khususnya risiko likuiditas dari sisi simpanan dan resiko kredit macet juga akan terus meningkat yang akan menyebabkan stabilitas perbankan akan mengalami penurunan.

Kemudian, terkait dengan pengaruh inflasi terhadap stabilitas perbankan. Hasil estimasi menunjukkan bahwa inflasi memiliki nilai signifikan terhadap indeks stabilitas perbankan. Hal ini menunjukkan bahwa ketika tingkat inflasi mengalami peningkatan akan menyebabkan bank menjadi tidak stabil karena indeks stabilitas perbankan juga mengalami peningkatan. Hal ini sesuai pula dengan penelitian yang dilakukan oleh Perry Warjiyo tahun 2006 yang menyatakan bahwa apabila perkembangan ketiga indikator (inflasi, nilai tukar, dan suku bunga) ini berlangsung stabil, maka semakin kecil pula risiko pasar yang dihadapi perbankan sehingga akan mendukung terjadinya stabilitas sistem perbankan (Warjiyo, 2006).

Meningkatnya inflasi maka akan membuat nilai mata uang akan menurun dan hal tersebut menyebabkan masyarakat enggan untuk menyimpan uang di bank karena harapan mendapatkan bunga di tengah inflasi yang tinggi. Oleh karena itu, masyarakat merasa tidak diuntungkan ketika menabung di bank, sedangkan dari sisi bank menyebabkan dana yang dihimpun akan menjadi lebih kecil dan mengganggu fungsi intermediasi bank. Sehingga, dengan meningkatnya inflasi jelas akan meningkatkan resiko pasar yang terkandung dalam neraca bank-bank yaitu dana yang dihimpun bank akan berkurang dan stabilitas bank di Indonesia akan mengalami penurunan yang ditunjukkan dengan indeks stabilitas perbankan yang tinggi. Hal ini sesuai dengan penelitian yang dilakukan oleh Rizki Yudaruddin tahun 2016 yang menunjukkan bahwa inflasi memiliki hubungan negatif terhadap z-score bank yang menunjukkan kestabilan bank dan secara implisit pada beberapa empiris lainnya (Acharya \& Ryan, 2016; Jayakumar et al., 2018; Ntarmah et al., 2019; Yudaruddin, 2016)

\section{IV.Kesimpulan}

Berdasarkan analisis dan pembahasan hasil penelitian yang telah dikemukakan di bab sebelumnya, maka dapat disimpulkan bahwa secara simultan, hasil penelitian menunjukkan adanya pengaruh signifikan antara variabel LDR, NPL, CAR, BI Rate, dan inflasi terhadap stabilitas perbankan di Indonesia. Selanjutnya, variabel LDR (Loan to Deposit Ratio) memiliki pengaruh signifikan terhadap stabilitas bank. Hasil ini menunjukkan ketika rasio ini mengalami peningkatan, bank harus mencairkan asetnya untuk pembiayaan kredit maka semakin buruk stabilitas perbankan dan tingkat likuiditas bank menjadi rendah. Lebih lanjut, variabel NPL (Non Performing Loan) memiliki pengaruh signifikan terhadap stabilitas bank. Hasil ini menunjukkan bahwa tingginya pertumbuhan kredit macet akan mengurangi perolehan laba dari kredit yang diberikan bank sehingga membuat ketidaklancaran perputaran kas dan akan berpengaruh pada buruknya stabilitas bank (Al-Khouri \& Arouri, 2016; Jayakumar et al., 2018; Warjiyo, 2006; Yudaruddin, 2016, 2018). Selanjutnya, variabel CAR (Capital Adequacy Ratio) memiliki pengaruh tidak signifikan terhadap stabilitas bank. Hasil ini menandakan bahwa bank umum yang mempunyai modal kecil akan rentan terhadap kebangkrutan, sehingga belum mampu mengoptimalkan kecukupan modal dalam menjaga ketahanan stabilitas perbankan. Kemudian, variabel BI Rate memiliki pengaruh signifikan terhadap stabilitas bank. Hasil ini menandakan bahwa meningkatnya BI Rate akan diikuti suku bunga kredit yang tinggi dan membuat risiko kredit debitur akan meningkat, sehingga risiko perbankan khususnya risiko likuiditas dan kredit macet mengalami peningkatan dan membuat buruknya stabilitas bank. Terakhir, variabel inflasi memiliki pengaruh signifikan terhadap stabilitas bank. Hasil ini menunjukkan bahwa meningkatnya inflasi akan diikuti turunnya nilai mata uang yang akan menyebabkan masyarakat enggan menabung di bank karena merasa tidak diuntungkan, sehingga dana yang dihimpun oleh pihak bank akan akan menjadi lebih kecil dan stabilitas bank akan terganggu.

Adapun saran yang dapat peneliti sampaikan berdasarkan hasil penelitian yang telah dilakukan adalah pertama, bagi bank umum di Indonesia, sebaiknya menentukan besaran modal yang harus ditahan dengan cermat dan tepat. Agar bank umum dapat memenuhi persyaratan standar modal internasional. Kedua, bagi pemegang kebijakan, sebaiknya terus mengawasi dan mengevaluasi kebijakannya terkait besaran modal yang wajib dimiliki bank 
umum, kegiatan usaha yang dilakukan oleh perbankan konvensional maupun perbankan syariah dan juga persyaratan pendirian suatu bank. Terakhir, yakni yang ketiga, bagi peneliti selanjutnya, diharapkan mampu memperluas analisis terkait faktor determinan yang mempengaruhi stabilitas perbankan secara mendalam dengan cara menambah ruang lingkup variabel penelitian, menambah variabel penelitian yang belum dibahas dalam penelitian ini serta memperluas rentang waktu dan objek penelitian.

\section{Daftar Pustaka}

Acharya, V. V., \& Ryan, S. G. (2016). Banks' Financial Reporting and Financial System Stability. Journal of Accounting Research, 54(2), 277-340. https://doi.org/10.1111/1475-679X.12114

Adrian, T., \& Liang, N. (2016). Monetary Policy, Financial Conditions, and Financial Stability (SSRN Scholarly Paper ID 2811090). Social Science Research Network. https://papers.ssrn.com/abstract $=2811090$

Al-Khouri, R., \& Arouri, H. (2016). The simultaneous estimation of credit growth, valuation, and stability of the Gulf Cooperation Council banking industry. Economic Systems, 40(3), 499-518. https://doi.org/10.1016/j.ecosys.2015.12.005

Basuki, A. T., \& Prawoto, N. (2016). Analisis Regresi Dalam Penelitian Ekonomi \& Bisnis: Dilengkapi Aplikasi SPSS \& EVIEWS. PT. Rajagrafindo Persada.

Bohl, M. T., Michaelis, P., \& Siklos, P. L. (2016). Austerity and recovery: Exchange rate regime choice, economic growth, and financial crises. Economic Modelling, 53, 195207. https://doi.org/10.1016/j.econmod.2015.11.017

Cahyaningrum, I. S. (2017). Pengaruh Sektor Riil dan Keuangan Syariah Terhadap Pertumbuhan Ekonomi di Indonesia Tahun 2007-2014. An-Nisbah: Jurnal Ekonomi Syariah, 4(1), 106-128.

Chiesa, G., \& Mansilla-Fernandez, J. M. (2018). Non-Performing Loans, Cost of Capital, and Lending Supply: Lessons from the Eurozone Banking Crisis (SSRN Scholarly Paper ID 3259066). Social Science Research Network. https://doi.org/10.2139/ssrn.3259066

Fahrial, F. (2018). Peranan Bank dalam Pembangunan Ekonomi Nasional. Ensiklopedia of Journal, 1(1), 179-184.

Gunawan, F. B. (2019). Hubungan Kausalitas Antara Sektor Keuangan Dan Sektor Riil di Indonesia. Jurnal Akuntansi, 11(1), 44-60.

Jamili, M. (2017). Pengaruh Pembiayaan Bank Syari'ah, Investasi dan Belanja Pemerintah terhadap Pertumbuhan Ekonomi di Indonesia. JIHBIZ, 1(1), 39-62.

Jayakumar, M., Pradhan, R. P., Dash, S., Maradana, R. P., \& Gaurav, K. (2018). Banking competition, banking stability, and economic growth: Are feedback effects at work? Journal of Economics and Business, 96, 15-41. https://doi.org/10.1016/j.jeconbus.2017.12.004

Korbi, F., \& Bougatef, K. (2017). Regulatory capital and stability of Islamic and conventional banks. International Journal of Islamic and Middle Eastern Finance and Management, 10(3).

Lamers, M., Mergaerts, F., Meuleman, E., \& Vander Vennet, R. (2016). The Trade-Off 
between Monetary Policy and Bank Stability (SSRN Scholarly Paper ID 2896747). Social Science Research Network. https://doi.org/10.2139/ssrn.2896747

Natarsyah, S. (2000). Analisis Pengaruh Beberapa Faktor Fundamental dan Risiko Sistematik Terhadap Harga Saham Kasus Industri Barang Konsumsi yang Go-Publik di Pasar Modal Indonesia. Journal of Indonesian Economy and Business, 15(3), 294312.

Ntarmah, A. H., Kong, Y., \& Gyan, M. K. (2019). Banking system stability and economic sustainability: A panel data analysis of the effect of banking system stability on sustainability of some selected developing countries. Quantitative Finance and Economics, 3(4), 709.

Ozili, P. K. (2019). Non-performing loans and financial development: New evidence. The Journal of Risk Finance, 20(1), 59-81. https://doi.org/10.1108/JRF-07-2017-0112

Purboyanti, R. T., \& Yogatama, A. N. (2018). Pengaruh Earning Per Share, Debt To Equity Ratio Dan Return On Equity Terhadap Saham LQ45. Jurnal IImiah Bisnis dan Ekonomi Asia, 12(2), 66-75. https://doi.org/10.32812/jibeka.v12i2.9

Ramly, A. R., \& Hakim, A. (2017). Pemodelan efisiensi bank di Indonesia: Perbandingan antara bank Syariah dan bank konvensional. Esensi: Jurnal Bisnis Dan Manajemen, 7(2), 131-148.

Risal, T. (2019). PENINGKATAN PERAN PERBANKAN SYARIAH DENGAN MENGGERAKKAN SEKTOR RIIL DALAM PEMBANGUNAN. Accumulated Journal (Accounting and Management Research Edition), 1(1), 36-47.

Setiawan, R., \& Pratama, A. A. P. (2019). Modal, Tingkat Likuiditas Bank, NPL dan Pertumbuhan Kredit Perbankan Indonesia (Capital, Level of Liquidity, Npland Credit Growth of Indonesian Banks). Matrik: Jurnal Manajemen, Strategi Bisnis Dan Kewirausahaan, 13(1), 96-107.

Siahaan, D., \& Asandimitra, N. (2018). Pengaruh Likuiditas Dan Kualitas Aset terhadap Profitabilitas pada Bank Umum Nasional (Studi pada Bursa Efek Indonesia Periode 2010-2014). BISMA (Bisnis Dan Manajemen), 9(1), 1-12.

Simatupang, B. (2019). Aspek yuridis UU No. 10 Tahun 1998 terhadap peranan perbankan dalam meningkatkan perekonomian Indonesia berdasarkan pancasila dan UUD 1945. Ensiklopedia Sosial Review, 1(1).

Simatupang, P., Supriyati, N., \& Mardianto, S. (2016). Pengaruh Teknologi terhadap Perubahan Peranan Sektor Pertanian dalam Struktur Perekonomian Indonesia. Jurnal Agro Ekonomi, 15(2), 1. https://doi.org/10.21082/jae.v15n2.1996.1-20

Utami, H. W. (2018). Analisa Pengaruh Sektor Perbankan Terhadap Pertumbuhan Ekonomi Indonesia Periode 2001-2015. OECONOMICUS Journal of Economics, 2(2), 20-30.

Warjiyo, P. (2006). Stabilitas sistem perbankan dan kebijakan moneter: Keterkaitan dan perkembangannya di Indonesia. Buletin Ekonomi Moneter Dan Perbankan, 8(4), 429-454-429-454.

Widyastuti, R. S., \& Armanto, B. (2013). Kompetisi industri perbankan Indonesia. Buletin Ekonomi Moneter Dan Perbankan, 15(4), 417-439.

Yang, C.-C. (2017). Reduction of non-performing loans in the banking industry: An application of data envelopment analysis. Journal of Business Economics and 
Management, 18(5), 833-851. https://doi.org/10.3846/16111699.2017.1358209

Yudaruddin, R. (2016). Dampak Faktor Makro Ekonomi Terhadap Stabilitas Bank Pembangunan Daerah Di Indonesia. Jurnal Conference on Management and Behavioral Studies.

Yudaruddin, R. (2018). Pengaruh konsenterasi dan ukuran bank serta inflasi terhadap stabilitas bank pembangunan daerah. INOVASI, 13(2), 127-134. 